\title{
PENGARUH PROMOSI MEDIA SOSIAL TERHADAP KEPUTUSAN BERKUNJUNG WISATAWAN KE KAMPUNG EROPA LEMBAH HARAU
}

\author{
M. RAFI WAL ADZAN ${ }^{1}$, TRISNA PUTRA ${ }^{2}$ \\ Program Studi D4 Manajemen Perhotelan, Jurusan Pariwisata, \\ Fakultas Pariwisata dan Perhotelan Universitas Negeri Padang ${ }^{1,2}$ \\ tpo3tra@gmail.com ${ }^{1}$
}

\begin{abstract}
Research on the Effect of Social Media Promotion in the European Village of Lembah Harau stems from the problem that the authors found, namely the lack of promotion through social media in the European Village. Promotion through social media is very important because it is useful for introducing or reaching out further to tourists so that they can improve their decision to visit Kampung Europe. And this research is also based on the needs of the Tourism and Youth Office of the Limapuluh Kota Regency in recording and increasing visits to tourist objects. This type of research uses quantitative research methods with a causal associative approach. The population of this study amounted to 3,120 and this research sample was taken using a non-probability sampling technique with a sample of 100 people. The instrument used in this study was a questionnaire that was structured using a Likert scale. The data in the study were processed with the help of the SPSS version 20 program. The analysis technique in this study was quantitative descriptive analysis method. The results showed that: (1). Social Media Promotion Variable (X) obtained results as much as $57 \%$ with the category strongly agree. (2). The Visiting Decision Variable (Y) obtained results as much as $48 \%$ in the category of agreeing. The results in this study that through simple linear regression test obtained F count 70,305 with Sig $0.000>0.05$ then the regression model can be used. Then HA is accepted and $\mathrm{HO}$ is rejected.
\end{abstract}

Keywords: Social Media Promotion, Visit Decision, European Village

Abstrak: Penelitian Pengaruh Promosi Media Sosial di Kampung Eropa Lembah Harau bermula dari permasalahan yang penulis temukan yaitu kurangnya promosi melalui media sosial di Kampung Eropa. Promosi melalui media sosial sangat penting karena berguna untuk memperkenalkan atau menjangkau lebih jauh wisatawan sehingga dapat meningkatkan keputusan berkunjung ke Kampung Eropa. Dan penelitian ini juga dilandasi dari kebutuhan Dinas Pariwisata dan Pemuda Kabupaten Limapuluh Kota dalam mendata dan meningkatkan kunjungan ke Objek wisata.

Jenis penelitian ini menggunakan metode penelitian kuantitatif dengan pendekatan assosiatif kausal. Populasi penelitian ini berjumlah 3.120 dan penelitian ini sampel diambil dengan memakai teknik non probability sampling memiliki sampel berjumlah 100 orang. Instrumen yang digunakan pada penelitian ini menggunakan kuesioner yang tersusun dengan menggunakan skala Likert. Data pada penelitian diolah dengan bantuan program SPSS versi 20. Teknik analisis pada penelitian ini adalah dengan metode analisis deskriptif kuantitatif.

Hasil penelitian menunjukan bahwa : (1). Variabel Promosi Media Sosial (X) didapat hasil sebanyak 57\% dengan kategori sangat setuju. (2). Variabel Keputusan Berkunjung (Y) didapat hasil sebanyak $48 \%$ katergori setuju. Hasil dalam penelitian ini yaitu dengan melalui uji regresi linear sederhana diperoleh $\mathrm{F}$ hitung 70.305 dengan Sig 0,000>0.05 maka model regresi dapat dipakai. Maka HA diterima dan HO ditolak.

Kata Kunci: Promosi Media Sosial, Keputusan Berkunjung, Kampung Eropa

\section{A. Pendahuluan}

Indonesia merupakan negara yang sangat indah dengan kekayaan alam yang sangat luas yang dimanfaatkan oleh masyarakat setempat untuk dijadikan objek wisata. Pariwisata merupakan kegiatan yang ditujukan untuk memberikan pelayanan wisata, memberikan dan memelihara daya tarik wisata, usaha pariwisata, dan usaha lain yang terkait di bidang ini [1].Pariwisata adalah "aktivitas seseorang yang pindah atau menetap di suatu tempat diluar 
lingkungan untuk waktu tidak lebih dari satu tahun berturut-turut, untuk kesenangan, bisnis atau tujuan lain.”[2]. Hal tersebut bertujuan untuk menarik kunjungan wisatawan yang berguna untuk meningkatkan devisa negara serta pendapatan masyarakat sekitar [3]. Dalam pengembangan pariwisata perlu keterlibatan stakeholder lain yang disebut dengan penta helix (Putra 2019) [4], peran aktif stakeholder penting dalam pengembangan daya tarik wisata (Putra 2018) [5], pemberdayaan kelompok sadar wisata. Salah satu keindahan alam indonesia terletak di Kabupaten Limapuluh Kota. Kabupaten Limapuluh Kota merupakan suatu daerah yang memiliki keindahan alam yg mengagumkan mulai dari pegunungan dan perbukitan yang menjanjikan untuk kepuasan wisatawan yang berkunjung ke kabupaten limapuluh kota. Dari beberapa keindahan alam yang ada di Lima Puluh Kota salah satrunya terletak di objek wisata Kampung Eropa. Kampung Eropa Lembah Harau merupakan destinasi wisata yang dibangun pada tahun 2018 dan mulai dibuka untuk umum pada tahun 2019. Kampung Eropa Lembah Harau terletak di Tarantang,Kecamatan Harau, Kabupaten Limapuluh Kota, Sumatera Barat. Kampung Eropa berada di lokasi yang sangat asri karena langsung diapit oleh lembah perbukitan dan disuguhkan pemanadangan air terjun Sarasah Bunta yang tidak terlalu jauh dari lokasi. Berdasarkan hasil observasi peneliti ditemukan kurangya promosi media sosial yang dilakukan pengelola sehingga memyebabkan kurangnya tingkat keputusan berkunjung wisatawan.

Tabel 1.Data kunjungan wisatawan Kampung Eropa Tahun 2019

\begin{tabular}{|c|c|c|}
\hline $\begin{array}{c}\mathrm{N} \\
\mathrm{o}\end{array}$ & Bulan & $\begin{array}{c}\text { Jumlah } \\
\text { Pengunjung }\end{array}$ \\
\hline 1 & Januari & 4.353 \\
\hline 2 & Februari & 3.252 \\
\hline 3 & Maret & 2.965 \\
\hline 4 & April & 3.125 \\
\hline 5 & Mei & 3.992 \\
\hline 6 & Juni & 4.251 \\
\hline 7 & Juli & 3.998 \\
\hline 8 & Agustus & 2.954 \\
\hline 9 & September & 2.818 \\
\hline 10 & Oktober & 1.223 \\
\hline 11 & November & 2.851 \\
\hline 12 & Desember & 1.725 \\
\hline \multicolumn{2}{|c|}{ Jumlah } & 37.437 \\
\hline
\end{tabular}

Sumber:Kantor Wali Nagari Tarantang 2019

Dari tabel di atas dapat diketahui bahwa pada tahun 2019 jumlah pengunjung yang datang ke objek wisata Kampung Eropa sebanyak 37.437 orang. Untuk jumlah pengunjung terbanyak tercatat pada Bulan Januari yaitu sebanyak 4.353 orang. Sedangkan pengunjung dengan jumlah terendah terdapat pada Bulan Oktober yaitu sebanyak 1.223 orang. Terdapat permasalahan di objek wisata Kampung Eropa. Pemasaran pariwisata melalui media internet terutama website (Putra et al. 2020) [6]. Dari segi promosi melalui media sosial, pihak pengelola Kampung Eropa kurang melakukan promosi terutama di media sosial sehingga mempengaruhi tingkat kunjungan dan keputusan berkunjung dari wisatawan. Hal ini dibuktikan dengan postingan di instagram kampung eropa, dilihat dari segi followers yang sedikit dan kurang aktifnya pengelola dalam memposting postingan terbaru kampung eropa. Media sosial merupakan alat promosi bisnis yang efektif karena dapat diakses oleh siapa saja, sehingga jaringan promosi bisa lebih luas[7]. Salah satunya dengan menggunakan situs jejaring sosial.Situs jejaring sosial adalah aplikasi yang mengizinkan pengguna untuk dapat terhubung dengan cara membuat informasi sehingga dapat terhubung dengan orang lain[8]. Langkah ini sangat efektif dilakukan pengelola kampung eropa dalam mempromosikan objek 
wisata. Kurangnya promosi media sosial tentunya akan berdampak besar bagi objek wisata terutama kampung eropa.

\section{B. Metodologi Penelitian}

Jenis penelitian pada penelitian ini adalah penelitian kuantitatif dengan pendekatan asosiatif kausal [9]. Populasi dan sampel pada penelitian ini yaitu wisatawan yang pernah berkunjung ke Kampung Eropa dengan 100 responden. Teknik pengambilan sampel peneltian ini yaitu non probality sampling [10]. Uji persyaratan analisis pada penelitian ini yaitu, uji normalitas homogenitas serta linearitas dengan bantuan SPSS 20.

\section{Hasil Dan Pembahasan}

Hasil

\section{Hasil Penelitian}

Pada bagian ini dibahas dan dipaparkan data yang terkumpul dari hasil penelitian yang dilakukan terhadap tamu yang pernah berkunjung ke objek wisata Kampung Eropa yang berjumlah 100 orang dari 4 indikator untuk variabel Promosi Media Sosial dengan 8 butir pernyataan dan untuk variabel keputusan berkunjung dengan 20 butir pernyataan yang telah diuji validitas serta reliabilitasnya. Hasil yang di dapat untuk variabel (X) promosi media sosial dan variabel (Y) keputusan berkunjung sebagai berikut:

\section{Tabel 2. Data Variabel (X) promosi media sosial}

\begin{tabular}{|c|c|c|c|}
\hline Kategori & Rentang skor & F & $\%$ \\
\hline Sangat Setuju & $\mathbf{Z}_{\mathbf{3 1}, 995}$ & $\mathbf{5 7}$ & $\mathbf{5 7}$ \\
\hline Setuju & $26,665-i 31,995$ & 32 & 32 \\
\hline Kurang Setuju & $21,335-i 26,665$ & 10 & 10 \\
\hline Tidak Setuju & $16,005-i 21,335$ & 1 & 1 \\
\hline Sangat Tidak Setuju & $i \cdot 16,005$ & 0 & 0 \\
\hline \multicolumn{2}{|c|}{ Jumlah } & 100 & 100 \\
\hline
\end{tabular}

Berdasarkan perhitungan statistik variabel Promosi Media Sosial (X) berada pada

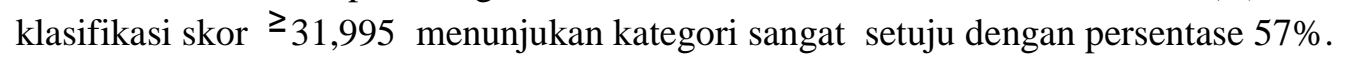

Tabel 3. Data (Y) Variabel Keputusan Berkunjung

\begin{tabular}{|c|c|c|c|}
\hline Kategori & Rentang skor & $F$ & $\%$ \\
\hline Sangat setuju & $\geq 79,995$ & 41 & 41 \\
\hline Setuju & $\mathbf{6 6 , 6 6 5}-i \mathbf{7 9 , 9 9 5}$ & $\mathbf{4 8}$ & $\mathbf{4 8}$ \\
\hline Kurang Setuju & $53,335-i 66,665$ & 10 & 10 \\
\hline Tidak Setuju & $40,005-i .53,335$ & 1 & 1 \\
\hline Sangat tidak setuju & $i .40,005$ & 0 & 0 \\
\hline \multicolumn{2}{|c|}{ Jumlah } & 100 & 100 \\
\hline
\end{tabular}

Berdasarkan perhitungan statistik variabel Keputusan berkunjung (Y) berada pada klasifikasi skor 66,665-<79,995 menunjukan kategori setuju dengan persentase $48 \%$.

Tabel 4. Nilai Signifikansi ANOVA $^{\mathrm{a}}$

\begin{tabular}{|rl|r|r|r|r|r|}
\hline \multicolumn{1}{|l|}{ Model } & \multicolumn{1}{|c|}{$\begin{array}{c}\text { Sum of } \\
\text { Squares }\end{array}$} & \multicolumn{1}{|c|}{ Df } & Mean Square & F & Sig. \\
\hline \multirow{3}{*}{1} & Regression & 3289.044 & 1 & 3289.044 & 70.305 & $.000^{\mathrm{b}}$ \\
& Residual & 4584.666 & 98 & 46.782 & & \\
& Total & 7873.710 & 99 & & & \\
\hline
\end{tabular}

a. Dependent Variable: TTLY

b. Predictors: (Constant), TTLX

Berdasarkan hasil uji anova diatas nilai F hitung 70.305 dengan Sig $0.000<0.05$ maka model regresi dapat dipakai. Artinya Promosi media sosial berpengaruh secara signifikan terhadap keputusan berkunjung. Maka Ha diterima dan Ho ditolak. 
Tabel 5. Koefisien Determinasi ( $R$ square) Variabel $X$ terhadap Variabel $Y$ Model Summary

\begin{tabular}{|l|r|r|r|r|}
\hline Model & R & R Square & $\begin{array}{c}\text { Adjusted R } \\
\text { Square }\end{array}$ & $\begin{array}{c}\text { Std. Error of } \\
\text { the Estimate }\end{array}$ \\
\hline 1 & $.646^{\mathrm{a}}$ & .418 & .412 & 6.840 \\
\hline
\end{tabular}

a. Predictors: (Constant), TTLX

Dari tabel di atas diperoleh nilai $\mathrm{R}$ square sebesar 0,418 hal ini berarti variabel Promosi media sosial berpengaruh terhadap Keputusan Berkunjung Wisatawan ke Objek Wisata Kampung Eropa Lembah Harau.

\section{Pembahasan}

\section{Promosi Media Sosial (X)}

Berdasarkan hasil pengolahan data dari 100 sampel, dengan menggunaan SPSS versi 20. Diketahui bahwa secara keseluruhan menunjukkan persentase sebesar 57\% pada rentang skor $\geq 31,995$ dengan kategori sangat setuju. Dengan demikian dapat disimpulkan bahwa promosi media sosial di Objek Wisata Kampung Eropa Lembah Harau secara keseluruhan dikategorikan sangat setuju.

\section{Keputusan Berkunjung (Y)}

Berdasarkan hasil pengolahan data dari 100 sampel, diketahui bahwa keputusan berkunjung ke Objek Wisata Kampung Eropa Lembah Harau secara keseluruhan menunjukkan persentase sebesar $48 \%$ pada rentang skor 66,665- i.79,995 dengan kategori setuju. Dengan demikian dapat disimpulkan bahwa keputusan berkunjung ke Objek Wisata Kampung Eropa Lembah Harau secara keseluruhan di kategorikan setuju.

\section{Pengaruh Promosi Media Sosial terhadap Keputusan Berkunjung wisatawan ke Kampung Eropa Lembah Harau}

Berdasarkan hasil uji hipotesis yang digunakan untuk mengetahui derajat pengaruh antara Promosi Media Sosial terhadap keputusan berkunjung wisatawan ke Kampung Eropa Lembah Harau, yang dilakukan dengan bantuan SPSS versi 20. Dalam penelitian ini hasil uji Regresi linear sederhana diperoleh $\mathrm{F}$ hitung 70.305 dengan sign $0,000<0,05$ maka artinya variabel Promosi Media Sosial (X) berpengaruh secara signifikan terhadap variabel Keputusan Berkunjung (Y), maka Ha diterima

Kemudian koefisien determinasi diperoleh R Square 0.418, artinya konstribusi varibel Promosi Media Sosial (X) terhadap variabel keputusan berkunjung (Y) adalah sebesar 0,6\% sedangkan 99,4\% ditentukan oleh faktor lain. Sebagaimana juga hasil penelitian yang telah dilakukan dapat dilihat bahwa diperoleh hasil koefisien regresi sebesar 1,447 yang artinya setiap peningkatan sebesar 1 satuan Promosi media sosial akan meningkatkan 1,447 satuan keputusan berkunjung.

Dengan demikian dapat dinyatakan bahwa secara keseluruhan Promosi Media Sosial berpengaruh positif signifikan terhadap keputusan berkunjung wisatawan ke Kampung Eropa Lembah Harau dapat dikatakan jika Promosi Media Sosial meningkat maka keputusan berkunjung Wisatawan ke Kampung Eropa Lembah Harau juga meningkat. Hal ini menunjukkan bahwa Promosi Media Sosial menjadi hal yang utama dalam proses pengambilan keputusan untuk berkunjung. Oleh karena itu, keputusan berkunjung ditentukan dengan seberapa baik Promosi Media Sosial.

\section{Penutup}

Simpulan

Berdasarkan hasil peneitian dan pembahasan yang telah dilakukan pada pembahasan sebelumnya maka dapat disimpulkan bahwa Promosi Media Sosial berpengaruh positif terhadap Keputusan Berkunjung ke Kampung Eropa Lembah Harau. 


\section{Saran}

Bagi Pengelola Objek Wisata Kampung Eropa Lembah Harau seperti yang telah dijelaskan pada pembahasan. Berdasarkan hasil penelitian ditemukan bahwa Promosi Media Sosial tidak berpengaruh secara signifikan sehingga objek wisata Kampung Eropa harus lebih fokus dalam melakukan promosi melalui media sosial dengan tujuan agar dapat menjangkat publik maupun wisatawan lebih jauh, sehingga tingkat kunjungan ke kampung eropa menjadi meningkat.

\section{Daftar Pustaka}

[1] Utama, A. Y., \& Nurgiyatna, S. T. (2017). Penggunaan Augmented Reality Sebagai Media Promosi Pariwisata Di Kabupaten Karanganyar (Doctoral dissertation, Universitas Muhammadiyah Surakarta).

[2] Wahid, A. (2015). Strategi Pengembangan Wisata Nusa Tenggara Barat Menuju Destinasi Utama Wisata Islami. Universitas Muhammadiyah Yogyakarta.

[3] Aprilia, F. (2015). Pengaruh Word Of Mouth Terhadap Minat Berkunjung Serta Dampaknya Pada Keputusan Berkunjung (Survei pada Pengunjung Tempat Wisata "Jawa Timur Park 2" Kota Batu). Jurnal Administrasi Bisnis, 24(1).

[4] Putra, Trisna. 2019." A Review on Penta Helix Actors in Village Tourism Development and Management. " Journal of Business on Hospitality and Tourism 5(1) :63. Doi: 10.22334/jbhost.v5i1.150.

[5] Putra, Trisna. 2018 "Daya Tarik Kota Lama Sebagai Objek Wisata Edukasi Di Kota Padang." Seminar Nasional Asosiasi Pendidikan Tekhnologi dan Kejuruan Indonesia (APTEKINDO) 2018.

[6] Putra, Trisna, Pasaribu Pasaribu, and Nidia Wulansari.2020. "Pemasaran wisata berbasis website di Nagari Wisata Harau Kabupaten Lima Puluh Kota. “ 2(1):18-27.

[7] Mila Setiawan, Fitri Aprilia (2015)" Pengaruh Daya Tarik, Fasilitas dan Aksesibilitas Terhadap Keputusan Wisatawan Asing Berkunjung Kembali” Jurnal Pelangi hlm 71-82

[8] Putra, Gede Lingga Ananta Kusuma, and Gede Pasek Putra Adnyana Yasa. "Komik sebagai sarana komunikasi promosi dalam media sosial." Jurnal Newala Visual 1.1 (2019): $1-8$

[9] Sugiyono.2018. Metode Penelitian kuantitatif kualitatif Dan $R \&$ D. Bandung :Alfabeta

[10] Sugiyono.2015. Metode Penelitian kuantitatif kualitatif Dan $R \&$ D. Bandung :Alfabeta 